\title{
The Effects of Rehabilitation Treatment on the Immune Cells and Cortisol Levels of Stroke Patients
}

\author{
Dong Sun Oh \\ Department of Clinical Pathology, Gwangyang Health College, Gwangyang 545-703, Korea
}

\section{뇌졸중 환자의 재활치료가 면역세포와 Cortisol에 미치는 영향}

\author{
오동선
}

광양보건대학교 임상병리과

\begin{abstract}
The purpose of this study was to investigate the effects of exercise through an in-hospital rehabilitation program on the enhanced immunity of immune cells and on the reduction of serum Cortisol, an indicator of physiological stress responses, among stroke patients. The 25 subjects were put to the program for two years from March 2, 2013 to February 28, 2015. The experimental group included 13 stroke patients from S and C Hospital in Gwangju, and the control group was composed of 12 common people. The findings were as follows: there were no significant differences in T cells between the experimental group with $69.18 \pm 11.78 \%$ and the control group with $70.75 \pm 6.33 \%$; there were significant differences in B cells between the experimental group $(12.95 \pm 3.74 \%)$ and the control group $(16.27 \pm 3.49 \%)$. Furthermore, there were no statistically significant increases of NK cells between the experimental group $(21.98 \pm 8.98 \%)$ and the control group $(15.72 \pm 5.07 \%)$ with $p<0.05$, though the values for the experimental group did rise. While there was elevated Cortisol before exercise in the experimental group $(p<0.05)$, which recorded $13.65 \pm 6.85 \%$ before and $9.90 \pm 4.66 \%$ after, there were no differences in the control group, which recorded $11.635 \pm 4.02 \%$ before and $12.64 \pm 2.30 \%$ after exercise. The present study also found continued exercise through an in-hospital rehabilitation exercise program increased differences in NK and T cells before and after exercise in the experimental group and thus had effects on enhanced immunity. Meanwhile, differences in Cortisol before and after exercise in the experimental group decreased, which indicates that the continued exercise was effective in reducing stress.
\end{abstract}

Keywords: Stroke, T cell, B cell, NK cell, Cortisol

This is an Open Access article distributed under the terms of the Creative Commons Attribution Non-Commercial License (http://creativecommons.org/licenses/by-nc/4.0) which permits unrestricted non-commercial use, distribution, and reproduction in any medium, provided the original work is properly cited.

Copyright () 2015 The Korean Society for Clinical Laboratory Science. All rights reserved.
Corresponding author: Dong Sun Oh Department of Clinical Pathology, Gwangyang Health College, Gwangyang 545-703, Korea Tel: 82-61-760-1556

E-mail: jmmods@hanmail.net

Received: April 30, 2015

Revised: May 28, 2015

Accepted: June 8, 2015

\section{서 론}

뇌졸중(Cerebral apoplexy)을 우리나라에서는 흔히 ‘중풍'이 라고 하며 뇌혈관장애로 인한 질환 및 사고를 일컫는 것으로, 순환 장애가 일어나 혈관이 터지거나 막힘으로써 의식장애와 신체에 마 비를 일으키는 ‘뇌혈관질환’이다(Kim 등, 2014).

우리나라 원인 별 사망률 중에서 뇌졸중은 암에 이어 두 번째이
고, 인구 10 만 명당 49.1명이다(국립중앙의료원사망통계, 2013). 뇌졸중(Cerebral apoplexy)의 원인에는 혈관 안에서 혈액이 굳어 서 된 고형물이 형성되는 혈전증(Thrombosis), 혈관 및 림프관 속 으로 운반되어 온 부유물이 혈관 내로 들어가 혈관의 협착 또는 폐 색을 일으키는 색전증(Embolism)과 출혈(Hemorrhage)등, 고혈 압, 심장질환, 당뇨병, 동정맥기형 또는 동맥류 등도 뇌졸중의 원인 에 기인한다(Kim 등, 2014). 이러한 뇌혈관질환 환자들을 치료하 
기 위하여 급성기 치료(약물치료인 혈전 용해제, 항응고제, 항혈소 판제)를 한 후 재활치료를 하게 되는데 이러한 중재의 목적은 최적 의 기능을 유지하도록 돕는데 있다.

재활치료, 운동, 면역반응은 서로 연관성이 있다. 운동과 면역과 의 관련성에 대한 연구는 1930년대를 기점으로 하여 이루어졌으 며, 최근의 연구에서 지구성 운동과 관련하여 인체의 면역반응에 대해 관심이 점점 높아지고 있으며, 운동 시 면역반응과 관련하여 가장 활발하게 연구가 이루어진 분야는 자연살해세포(natural killer cell; NK cell)의 반응으로서, NK cell은 림프구아군(lymphocytes subset)으로 종양세포와 바이러스에 감염된 세포들을 직 접적으로 세포독성(cytotoxic)을 발휘하여 바이러스 감염에 대한 강력한 방어역할을 하는 것으로 생각된다(Herberman, 1981). 면 역에 관계하는 세포에는 Lymphocyte (T cell, B cell, NK cell), Macrophage, Monocyte, 과립구(Neutrophil, Eosinophil, Basophil)등이 있는데, 이들의 기능은 광범위하게 생체를 방어하는 역할을 하며, 몇몇 세포들은 계속적으로 순환하면서 조직 내에 잠 재해 있고, 전체기관들을 재순환하면서 순찰한다. 궁극적으로 이 물질을 죽이고 손상된 조직을 재생시킨다(Nehlsen-Cannarella, 1998).

특히, NK cell은 T세포 독성이나 억제세포(suppressor cell)에 의해 영향을 받고, 보조 T세포(helper T cell) 또는 유도물(inducer $\mathrm{T}$ cell), 그리고 B cell에 의해 영향을 받는데, 운동과 관련하여 세포 기능의 변화에서 NK cell의 기능은 고강도의 운동 시나 운동 후에 증가 되었다(Maisel et al, 1989). 면역반응에서 운동뿐 아니라 영 양상태, 과도한 심리적 스트레스에 노출될 때 면역기능에 부정적인 영향을 미친다(Choi, 1995; Park, 1996; Yeo and Kim, 1996)고 보고되었다. 규칙적인 운동 활동이 환자들의 삶의 질을 향상 시킨 다는 연구(Valenti et al., 2008)가 있으며, 역학적인 연구에서 사람 의 특성에 상관없이 규칙적인 운동 활동을 한 그룹의 여성이 규칙 적인 운동을 하지 않은 그룹에 비하여 유방암에 걸릴 확률이 현저 하게 적게 나타났으며(Fitzgerald, 2007), 자연살해세포(natural killer cell; NK cell)의 활성도가 증가 되었다.

따라서 본 연구는 재활치료 병동에서 뇌졸중환자들을 대상으로 실험 군으로는 광주 시내 병원 중 S대 병원과 $\mathrm{C}$ 병원에서 재활치료 환자 중 운동치료를 할 수 있고 긍정적인 사고방식 즉 적극적인 재 활운동에 임하는 환자 중 실험군 13 명과 대조군으로는 뇌졸중이 발생될 수 있는 연령층을 고려하여 일반인 중 학생, 주부, 직장인 12 명을 선정하였다.

재활운동과 면역성의 관련성을 연구하기 위하여 병원 내 각각의 재활운동프로그램을 통해서 지속적인 운동으로 면역세포( $\mathrm{T}$ cell, $\mathrm{B}$ cell, NK cell)가 면역기능과 면역력 향상에 미치는 영향을 구명
하고, 생리적 스트레스 반응의 지표인 혈청 Cortisol이 면역력에 미 치는 영향과 스트레스를 줄이는데 효과가 있는지 보고자하며, 운동 프로그램을 통해서 자신의 신체적, 정서적, 심리적, 직업적, 잠재력 을 극대화하고 자족하는 삶을 살아갈 수 있도록 하는데 목적이 있 는 것이다.

\section{재료 및 방법}

\section{1. 연구 대상}

본 연구는 재활치료 병동에서 뇌졸중 환자 중에서 긍정적인 사 고력과 적극적인 재활에 임하는 환자를 선별하여 환자들의 각각 상 황에 맞게 물리치료실에서(중추신경 발달 치료 및 보행훈련), 작업 치료실에서(특수작업치료 및 인지치료) 60 분, 자가 운동(걷기, 달 리기) 40 분을 제공하고 평가하기 위해 면역세포 T-cell의 세포표 면표지(Cluster of differentiation marker) $\mathrm{CD} 3, \mathrm{CD} 4, \mathrm{CD}$, B-cell (CD19), NK cell (CD16+56) 와 환자의 재활에 따른 생리적 스트레스 반응의 지표인 혈청 코티솔을 측정하였다. 총 연구 기간 은 2013년 3월 2일부터 2015년 2월 28일까지 2년간 진행하였다.

\section{2. 연구 진행 과정}

\section{1) 연구 대상자 선정}

대상자 선정을 위해 광주 시내 병원 중 $\mathrm{S}$ 대 병원과 $\mathrm{C}$ 병원의 환자 들을 병록지를 검토하여 연구에 적합한 대상자의 목록을 작성하였 다. 구체적인 선정 기준은 다음과 같다.

· 연구 목적을 이해하고 연구의 참여할 것을 동의한 자

· 40세 79세 미만의 남녀

· 뇌졸중과 심근경색 환자 중 긍정적인 사고방식을 가진 자(하고 자 하는 의지력)

\section{· 뇌졸중 이외의 다른 장애가 없는 자}

· 혈액검사(CBC) 수치가 $\mathrm{Hb}$ (hemoglobin) $10 \mathrm{~g} / \mathrm{dl}$ 이상, WBC 가 $4,000 / \mathrm{mm}^{3}$ 이상, PLT가 $150,000 / \mathrm{mm}^{3}$ 이상인 자.

· 면역기능에 영향을 줄 만한 약물을 복용하지 않은 자

위 조건을 만족하는 자 중에서 개별면담을 통해 실험 군으로는 광주에 있는 $S$ 대 병원과 $C$ 병원의 뇌졸중 환자 13 명과 대조군으로 는 일반인(학생, 주부, 직장인) 12명을 선정하였다.

연구자는 보건복지 인력개발원에서 실시하는 연구윤리(Institute review board)의 이해 연구자 과정을 수료 하였으며, 대상자는 IRB 기준인 연구의 목적과 배경, 방법, 예상되는 위험, 개인정보 보 호에 대한 비밀상태, 연구 참여에 대한 손실에 대한 보상, 불이익이 있을 시 중도포기 등의 설명을 듣고 이해한 후 자발적인 의사에 따 라 서면동의를 하였으며 추가적인 정보, 의문시 연락대상 및 연락 
처를 사후조사, 의문사항을 위하여 연락처를 제공했다. 대상자로 부터 얻은 자료는 연구목적 이외에는 공개되지 않도록 관리하며 IRB 기준에 의한 목적으로만 사용하기로 하였다.

\section{3. 연구방법}

연구자는 대상자들에게 재활치료 목적과 방법을 설명한 후 4 주 재활치료 전후로 각각 1 회씩 검체를 채취하였고, 검체는 NCCLS (National Committee for Clinical Laboratory Standards) H42-A guideline기준(대한진단검사의학회지19권 1호 13-13)에 따른 혈 액 $5 \mathrm{ml}$ 를 채혈하여 항응고제가 든 K2 EDTA에 전혈 $2 \mathrm{ml}$ 로 면역세 포검사와 진공 채혈관에 혈액 $3 \mathrm{ml}$ 를 분주한 다음 혈청을 분리하여 코티솔을 검사하였다.

분석 장비는 BECKMAN COULTER사의(Cytomics FC-500, Beckman, USA) 시약은COULTER사의(Immunotech IO, Beckman, USA)시약을 사용하였다.

검사는 형광항체법으로(Fluorescent antibody method) 각각 특징적인 항원에 대한 FITC 또는 PE가 부착된 단클론 항체를 이중 염색하여 림프구와 반응시키면 FITC가 부착된 항체와 반응하는 세 포는 녹색형광 (maximum emission $525 \mathrm{~nm}$ )이 측정되고 $\mathrm{PE}$ (maximum emission $575 \mathrm{~nm}$ )가 붙은 항체와 반응하는 세포는 붉 은 형광물질을 유세포 분석기(flow cytometry)로 분석하면 이들 림프구의 종류에 따른 백분율을 측정할 수 있다. CD45 gating을 한 경우는 PE 나 FITC가 아닌 다른 형광(PC-5)이 부착된 CD45를 사 용한다. 코티 솔은 녹십자의료재단에서 방사면역측정법인 RIA (radioimmunoassay)방식으로 분석하였다. 코티솔 참고치는 오전 8시에 5.0-25.0 $\mu \mathrm{g} / \mathrm{dl}$, 오후 4시에 2.5-12.5 $\mu \mathrm{g} / \mathrm{dl}$,이다. 일중 시
간대별 변화를 고려하여 운동 전에는 오전 8시에, 운동 후에는 오후 5시로 일관되게 유지하였다.

\section{4. 자료처리방법}

본 연구 자료 분석은 SPSS/Window (version12.0)를 이용하여 Kolmogorov-smirnov 검정 결과 얻어진 데이터가 정규성을 보여 모수검정을 적용하였다. 일반적 특성은 빈도분석과 독립표본 $\mathrm{t}$ - 검 정을, 운동 전 - 후 비교는 대응 t-검정(paired t-test)을 실시하였 고, 대조군과 실험군 간의 전 · 후 유의성을 알아보기 위하여 반복 측정 분산분석(Repeated Measures Analysis of Variance)을 실시 하였다. 모든 통계처리에 대한 유의수준 $\alpha=0.05$ 로 설정하였다.

\section{결 과}

면역세포(T cell, B cell, NK cell)와 생리적 스트레스 반응의 지 표인 혈청 Cortisol의 참고치는 Table 1과 같다.

\section{1. 실험군과 대조군의 일반적 특성}

실험군과 대조군의 일반적 특성은 성별, 나이로 구분하여 나타 냈다. 실험군의 성별은 남 7명(53.8\%), 여 6명(46.2\%), 대조군에서 는 남 4 명(33.3\%), 여 8명(66.7\%)로 나타났고, 나이는 실험군의 뇌 졸중 환자의 특성상 50 세 이상에서 11 명(76.9\%), 50세 이하에는 2 명(23.1\%),대조군에서는 50 세 이상에서는 7명(58.3\%), 50세 이하 에서는 5명(41.7\%)나타났다(Table 2).

대조군의 선정은 뇌졸중이 발생될 수 있는 연령층을 고려하여 선정되었고, 실험군에서는 뇌졸중 환자의 구조적 특성과 환자면담

Table 1. Immunocyte and cortisol of analyzer reference value

\begin{tabular}{|c|c|c|c|c|c|}
\hline Immunocyte & Sample & Indicator & Method & \multicolumn{2}{|c|}{ Reference value } \\
\hline $\mathrm{T}$ cell & Whole Blood & CD3 & flow cytometer & \multicolumn{2}{|c|}{$(62.8-75.0 \%)$} \\
\hline B cell & Whole Blood & CD19 & flow cytometer & \multicolumn{2}{|c|}{$(6.3-19.9 \%)$} \\
\hline NK cell & Whole Blood & CD16+56 & flow cytometer & \multicolumn{2}{|c|}{$(7.4-23.6 \%)$} \\
\hline \multirow[t]{2}{*}{ Cortisol } & Serum & - & RIA & Morning & $5.0-25.0 \mu \mathrm{g} / \mathrm{dl}$ \\
\hline & & & & Afternoon & $2.5-12.5 \mu \mathrm{g} / \mathrm{dl}$ \\
\hline
\end{tabular}

Table 2. General characteristic of test group\&control group $(n=25)$

\begin{tabular}{|c|c|c|c|c|c|}
\hline \multirow{2}{*}{\multicolumn{2}{|c|}{ Parameters }} & \multirow{2}{*}{$\begin{array}{c}\text { Test group (\%) } \\
\text { frequency }\end{array}$} & \multirow{2}{*}{$\begin{array}{c}\text { Control group (\%) } \\
\text { frequency }\end{array}$} & \multirow{2}{*}{$\chi^{2}$} & \multirow{2}{*}{$p$ value } \\
\hline & & & & & \\
\hline \multirow[t]{2}{*}{ Sex } & Male & 7 (53.8) & $4(33.3)$ & 0.428 & 0.274 \\
\hline & Female & $6(46.2)$ & $8(66.7)$ & & \\
\hline \multirow[t]{2}{*}{ Age } & Under 50 & $2(23.1)$ & $5(41.7)$ & 0.202 & 0.173 \\
\hline & Over 50 & $11(76.9)$ & 7 (58.3) & & \\
\hline Total & & $13(100.0)$ & $12(100.0)$ & & \\
\hline
\end{tabular}


과정에서 50 세 이상에서 11 명 $(76.9 \%)$ 이 선정되었다.

뇌졸중 환자의 발병은 뇌졸중 환자 특성상 50 대 이상에서는 뇌 혈전, 뇌출혈이 증가하고 있으며 최근에는 30-40세대서 뇌색전증 환자가 증가하고 있다.

\section{2. 실험군과 대조군의 운동전 후의 평균과 표준편차}

실험 대상의 실험군과 대조군의 면역세포(T cell, B cell NK cell)와 Cortisol의 측정치는 다음과 같다.

$\mathrm{T}$-cell의 실험군 운동전 $65.70 \pm 11.02 \%$, 실험군 운동 후 $69.18 \pm 11.78 \%$, 대조군 운동전 $69.15 \pm 8.16 \%$, 운동 후 $70.75 \pm$ $6.33 \%, \mathrm{~B}$ cell의 실험군 운동전 $15.32 \pm 4.38 \%$ 운동 후 $12.95 \pm 3.74 \%$ 대조군 운동전 $16.92 \pm 3.87 \%$ 운동 후 $16.27 \pm 3.49 \% \mathrm{NK}$ cell의 실험군 운동전 $19.31 \pm 8.03 \%$ 운동 후 $21.98 \pm 8.98 \%$ 대조군 운동 전 $16.0 \pm 5.52 \%$ 운동 후 $15.72 \pm 5.07 \%$ Cortisol 실험군 운동전 $13.65 \pm 6.85 \%$ 운동 후 $9.90 \pm 4.66 \%$ 대조군의 운동전 $11.64 \pm$ $4.02 \%$ 운동 후 $12.64 \pm 2.30 \%$ 의 평균과 표준편차가 나왔다(Table 3 ).
따라서 Tcell의 실험군에서는 운동전 $65.70 \pm$ (11.02), 운동 후 $69.18 \pm$ (11.78) 유의한 차이는 없었으나 $(p=.95)$ 운동 후에 증가함 을 알 수 있었다. B cell의 경우 실험군에서 운동전 $15.32 \pm$ (4.38) 운동 후 $12.95 \pm$ (3.74)이었으나 통계적으로 유의수준 5\%수준에 서 통계적으로 유의한 차이를 보였다( $p=.014)$. 또한 NK cell 실험 군에서는 운동전19.31 \pm (8.03) 운동 후 21.98 \pm (8.98)로 운동 후 가 유의하게 증가 하였고, 생리적 스트레스 반응 지표인 혈청

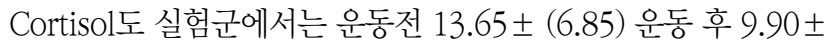
(4.66) 감소하여 유의함을 알 수 있었으며 스트레스를 줄이는데 효 과가 있음을 알 수 있었다(Table 4, 5).

\section{고 찰}

본 연구는 뇌혈관질환 환자들을 치료하기 위해서는 급성기 치료 를 한 후 재활치료를 하는데 환자를 대상으로 4주 동안 1 주에 3 회씩 환자들의 각각 상황에 맞게 물리치료실에서(중추신경 발달 치료 및

Table 3. Pre \& post Comparisons of experimental and Control group (mean \& SD) $(n=25)$

\begin{tabular}{|c|c|c|c|c|c|}
\hline & \multirow{2}{*}{ Group } & \multicolumn{2}{|c|}{ Mean \pm SD } & \multirow{2}{*}{$\mathrm{t}$} & \multirow{2}{*}{$p$ value } \\
\hline & & pre $(\%)$ & post (\%) & & \\
\hline \multirow[t]{2}{*}{ T Cell } & Control group & $69.15 \pm 8.16$ & $70.75 \pm 6.33$ & -1.704 & 0.116 \\
\hline & Experiment group & $65.70 \pm 11.02$ & $69.18 \pm 11.78$ & -1.812 & 0.095 \\
\hline \multirow[t]{2}{*}{ B Cell } & Control group & $16.92 \pm 3.87$ & $16.27 \pm 3.49$ & 2.29 & 0.043 \\
\hline & Experiment group & $15.32 \pm 4.38$ & $12.95 \pm 3.74$ & 2.86 & $0.014^{*}$ \\
\hline \multirow[t]{2}{*}{ NK Cell } & Control group & $16.00 \pm 5.52$ & $15.72 \pm 5.07$ & 0.345 & 0.737 \\
\hline & Experiment group & $19.31 \pm 8.03$ & $21.98 \pm 8.98$ & -1.465 & 0.165 \\
\hline
\end{tabular}

${ }^{*} p<0.05$. pre, Before exercise in the experiment; post, After exercise in the experiment.

Table 4. Comparisons of Cortisol in the experimental and Control group (mean \& SD) ( $n=25)$

\begin{tabular}{clclcc}
\hline \multirow{2}{*}{ Group } & Harmone & \multicolumn{3}{c}{ Cortisol } \\
\cline { 3 - 6 } & & Test $(\mathrm{M} \pm \mathrm{SD})$ & Time & Reference & $p$-value \\
\hline experiment & pre & $13.65 \pm 6.85$ & Morning & $5.0-25.0 \mu \mathrm{gg} / \mathrm{dl}$ & 0.019 \\
group & post & $9.90 \pm 4.66^{*}$ & Afternoon & $2.5-12.5 \mu \mathrm{g} / \mathrm{dl}$ & \\
Control & pre & $11.64 \pm 4.02$ & Morning & $5.0-25.0 \mu \mathrm{g} / \mathrm{dl}$ & 0.220 \\
group & post & $12.64 \pm 2.30$ & Afternoon & $2.5-12.5 \mu \mathrm{g} / \mathrm{dl}$ & \\
\hline
\end{tabular}

${ }^{\star} p<0.05$. pre, Before exercise in the experiment; post, After exercise in the experiment.

Table 5. Comparison of difference value of expeimental and Control group ( $n=25)$

\begin{tabular}{lccccc}
\hline & SS (III type) & DF & MS & F & $p$ value \\
\hline T Cell & 10.894 & 1 & 10.894 & 0.724 & 0.403 \\
B Cell & 9.312 & 1 & 9.312 & 3.654 & 0.068 \\
NK Cell & 27.199 & 1 & 27.199 & 2.061 & 0.165 \\
Cortisol & 70.732 & 1 & 70.732 & 8.585 & $0.008^{*}$ \\
\hline
\end{tabular}

${ }^{*} p<0.05$. SS, Sum of squares; DF, Degrees of freedom; MS, Mean square. 
보행훈련), 작업치료실에서(특수작업치료 및 인지치료) 60 분, 기 본적으로 하고 개인능력에 따라자가운동(걷기, 달리기)을 40 분 실 시하여 운동전과 운동 후의 면역반응과 생리적 스트레스 반응의 지 표인 혈청 Cortisol이 스트레스를 줄이는데 효과에 대한 변화를 실 시하였다.

운동 후에 대한 면역반응의 변화에 관한 선행연구에서 총 림프 구와자연살해세포의 상대적 변화는 24 시간 내에 운동전 수준으로 돌아왔고(Robertson 등, 1981; Kim 등, 2005), 체력을 소모하는 12-18분에서 피곤할 때까지 60분간 사이클링 운동을 한 연구 (Brahmi 등, 1985; Kim 등, 2005)에서는 자연살해세포가 증가하 였다가, 운동 후 120 분에는 감소하고, 24 시간 후에는 운동전 수치 로 돌아왔다는 보고를 하였다.

본 연구에서는 Tcell의 실험군에서는 운동전 $65.70 \pm 11.02 \%$, 운동 후 $69.18 \pm 11.78 \%$, 대조군 운동전 $69.15 \pm 8.16 \%$ 운동 후 $70.75 \pm 6.33 \%$ 로써 통계적으로 실험군과 대조군의 군간 유의한 차 이는 없었다. B cell의 실험군 운동전 $15.32 \pm 4.38 \%$ 운동 후 $12.95 \pm 3.74 \%$ 대조군 운동전 $16.92 \pm 3.87 \%$ 운동 후 $16.27 \pm 3.49 \%$ 로서 대조군에서는 유의하지 않았으나 실험 군에서 유의수준 5\% 수준에서 통계적으로 유의한 차이를 보였다 $(p=0.014)$. 그러나 INK cell에서는 실험군 운동전 $19.31 \pm 8.03 \%$ 운동 후 $21.98 \pm 8.98 \%$ 대조군 운동전 $16.0 \pm 5.52 \%$ 운동 후 $15.72 \pm 5.07 \%$ 로써 NK cell 의 비율이 통계상 유의하지 않았다 ( $p=0.95, \mathrm{SD}=8$ 이상). 그 이유는 실험군 환자 중 일부가 낮은 결과치를 얻어서 환자와 면담결과 영 양상태 저하, 과도한 정신적, 심리적 스트레스 증가, 높은 연령층에 서 운동력감소로 나타난 것으로 판단된다. 그러나 실험군에서 운동 전보다 운동 후가 증가 하였고, 또한 대조군 $15.72 \pm(5.07) \%$ 비에 실험군 운동 후가 $21.98 \pm$ (8.98)\%로 현저하게 수치가 증가하였음 을 알 수 있었다.

Cortisol 실험군에서는 운동전 $13.65 \pm 6.85 \%$ 운동 후 $9.90 \pm$ $4.66 \%$ 대조군에서 운동전 $11.64 \pm 4.02 \%$ 운동 후 $12.64 \pm 2.30 \%$ 로써 대조군에서는 두 군의 차이가 유의하지 않았으나, 실험군에서 는 운동전보다 운동 후가감소하여 유의함을 알 수 있었다 $(p<0.05)$. 혈청 코티솔은 일부 환자에서 운동 후 유의하게 감소하지 못하였 다. 그 이유는 크게 두 가지로 추론되는데 혈청 코티솔 측정에서 일 중 변동을 고려하여 혈액채취를 운동전인 경우 오전 8시와 운동 후 경우에는 오후 5시로 계획하였지만 대조군의 경우 대상자들의 주 거지와 거리상의 문제와 운영상의 문제로 오전 9시에서 10시 사이 에 혈액채취를 하였다. 또한 실험군인 운동전에는 병원 특성상 오 전 8시에 혈액을 채취할 수 있었지만 운동 후에는 환자들의 각각 운 동시간이 다르고 개인능력에 따라 자가 운동(걷기, 달리기)에 따라 오후 7시에 채취하는 환자들 경우는 혈청 코티솔은 일중 변동영향
으로 감소하지 않아나 생각이 된다. 그러나 NK 세포에서는 환자군 13 명 중 자가 운동(걷기, 달리기) 40 분을 실시한 환자 9 명에서는 다 른 환자들보다 현저하게 증가하였으며, NK-cell의 실험군의 운동 후 값이 $21.98 \pm 8.98 \%$ 로 표준편차가 큰 경우도 운동력이 떨어진 환자군에서 reference value값 보다 낮은 경우가 있어 표준편차가 높은 것으로 사료되며, 저강도보다 고강도가 NK-cell이 증가하는 것으로 사료된다.

선행연구들을 보면 $\operatorname{Kim}$ (1996)은 유도 선수 10명을 대상으로 고강도기와 저 강도기 트레이닝을 시킨 결과, 림프구 수는 고강도 기가 저 강도기보다 유의하게 감소하게 나타났으며, $\mathrm{T}$ 세포와 $\mathrm{B}$ 세 포 수의 변화에서도 고강도기가 저 강도기에 비해 모두 감소하여, 특히 T 세포 수는 저 강도기에 증가하였다. NK 세포에서는 오히려 고강도기에 높게 나타났다고 보고하였다. 한편 Moyna 등(1996)은 급성 운동 후 T cell, B cell 비율이 운동 전에 비해 유의하게 감소하 였고, NK cell의 비율은 유의하게 증가한다고 하였다. 엘리트 수영 선수들을 대상으로 최대 산소 섭취량의 $95 \%$ 수준인 강한 강도의 운 동 후 T cell, B cell의 비율은 증가하며 NK cell은 감소한다고 보고 되었다(Karagotich 등, 1997). 본 연구 결과에서는(Moyna 등, 1996), 연구 결과와 비교 시 B cell에서는 일치하지 않았고, T cell 과 NK cell에서는 일치하였다.

Fitzgerald (2007)의 유방암환자연구에서 사람의 특성과 상관 없이 규칙적인 운동을 한 여성그룹과의 결과 비교 시 본 실험군에 서도 NK cell이 증가하는 것도 일치 하였다.

운동 프로그램이 유방암 환자에서 자연살해 활성도가 방사선치 료를 했음에도 불구하고 감소되지 않고 증가 되었다(Chae 등, 2002)는 연구 결과와의 비교 시에도 NK cell이 증가하는 것도 본 논문과 일치 하였다.

$\operatorname{Kim}$ (1996)의 유도 선수 10명을 대상으로 고강도기와 저 강도 기 트레이닝을 시킨 결과와의 비교 시 림프구수가 감소하는 것과 특히 T세포가 증가하는 것은 일치 하였다.

한편 생리적 스트레스 반응의 지표인 혈청 Cortisol이 스트레스 를 줄이는데 효과가 있는지 보고자 운동 전. 후를 측정한 결과 실험 군에서 운동전 보다 운동 후가 혈청 Cortisol이 감소하여 스트레스 를 줄이는데 효과가 있음을 알 수 있었다.

그러므로 규칙적인 운동 활동이 환자들의 삶의 질을 향상 시킨 다는 선행논문에 있듯이 규칙적인 운동과 재활환자의 운동프로그 램을 통해서 자신의 신체적, 정서적, 심리적, 직업적, 잠재력을 극 대화하고 자족하는 삶을 살아갈 수 있도록 하는데 목적이 있었으 며, 규칙적인 운동은 인체 여러 측면에서 건강 증진에 득이 되는 것 은 잘 알려진 사실이며, 고강도의 탈진적인 운동은 인체 면역 억제 뿐만 아니라 산화적 손상을 유발하는 것으로 알려져 있다. 따라서 
개인에게 맞는 운동 강도와 운동량의 설정은 무엇보다 중요하며, 운동 치료는 근육의 기능을 향상시키는 것으로 환자 자신, 기관의 재활프로그램, 치료사에 의해 좌우될 것이다. 제한점으로는 뇌졸 중환자의 연령과 성별에 따른 병원 특성상 실험군과 대조군의 선정 시 한계가 있었으며 또한 환자군의 나이별, 질병 분류별로 연구가 이루어져야 할 것으로 사료되며 추후 이러한 연구 시 관련된 요인 들을 잘 파악하여 시행 되어야 할 것이다.

\section{요 약}

본 연구의 목적은 뇌졸중 환자가 병원 내 재활운동 프로그램을 통해서 지속적으로 운동 시에 면역세포(T cell, B cell, NK cell) 등 이 면역력 향상에 미치는 영향을 구명하고, 생리적 스트레스 반응 의 지표인 혈청 Cortisol이 스트레스를 줄이는데 효과가 있는지 보 고자 하였다. 연구 대상은 2013년 3월2일부터 2015년 2월 28일까 지 2년간 실시하였으며, 실험군으로는 광주에 있는 $S$ 대 병원과 $C$ 병 원의 뇌졸중 환자 13 명, 대조군으로는 일반인(학생, 주부, 직장인) 12 명을 선정하여 총 25 명을 대상으로 연구하였다. 본 연구 결과는 T cell의 실험군에서는 $69.18 \pm 11.78 \%$, 대조군에서는 $70.75 \pm 6.33 \%$ 로써 통계적으로 실험군과 대조군의 유의한 차이는 없었다. 한편 B cell의 실험군에서는 $12.95 \pm 3.74 \%$ 이고 대조군에서는 $16.27 \pm$ $3.49 \%$ 로써 실험군과 대조군의 유의한 차이를 보였다. NK cell의 실험군에서는 $21.98 \pm 8.98 \%$ 대조군에서는 $15.72 \pm 5.07 \%$ 로써 NK cell의 비율이 통계상 유의하게 증가하지 않았지만 $(p<0.05)$, 실험군에서 수치가 증가하였음을 알 수 있었다. Cortisol은 실험군 운동전 $13.65 \pm 6.85 \%$ 실험군 운동 후 $9.90 \pm 4.66 \%$, 대조군 운동 전 $11.635 \pm 4.02 \%$ 대조군 운동 후 $12.64 \pm 2.30 \%$ 대조군에서는 두 군의 차이가 유의하지 않았으나, 실험군에서는 유의하게 증가하 였다 $(p<0.05)$. 선행연구에서 단기간의 최대운동이나 중등도의 운 동 후 면역세포의 활성이 증가됨을 보고하였고, 본 연구에서도 병 원 내 재활운동 프로그램을 통해서 지속적인 운동으로 면역세포 중 $\mathrm{NK}$ cell의 실험군의 전후 차와 T cell에서 실험군의 전후 차가 증가 하여 면역력 향상에 영향이 있음을 알 수 있었고, Cortisol의 실험 군의 전후 차는 감소하여 스트레스를 줄이는데 효과가 있음을 알 수 있었다.

\section{Acknowledgements: None}

Funding: None

Conflict of interest: None

\section{References}

1. Brahmi Z, Thomas J, E, Park M, Dowdeswell I, R. The effect of acute exercise on natural killer cell activity of trained and sedentary human subjects. J Clin Immunol. 1985, 5:321-327.

2. Chae YR, Choe MA, Kim MJ. Effect of Exercise on Natural Killer Cell Cytotoxic Activity in Breast Cancer Patients. Korean Association of Medical Journal Editors. 2002, 7:59-68.

3. Choi BJ. Immunity and Exercise. korean society of sport. 1995 , 4:187-191.

4. Fitzgerald B. Regular exercise improves quality of life and physical fitness in women with breast cancer. Evid Based nurs. 2007, 10:1-12.

5. Herberman PB. Natural killer(NK) cells and their possible roles in resistance against disease. Clin. Immunol. 1981, 1:1-65.

6. Karagotich S, Keast D, Goodman C, Crawford G, Moirton A. The influence of blood volume changes on leucocyte and lymphocyte subpopulations in elite swimmers following interval training of varying intensities. J Sports Med. 1997, 18:373-380.

7. Kim KJ. Changes of Immune Parameters Following Training Sessions of Different Intensities. The Korean Journal of Sports Medicine. 1996, 2:817-823.

8. Kim KS, Lee SW, Choe MA, Yi MS, Choi SM, Kwon SH. Effects of abdominal breathing training using biofeedback on stress, immune response and quality of life in patients with a mastectomy for breast cancer. J Korean Acad Nurs. 2005, 35:1295-1303.

9. Kim YH, Gang CY, et al. Public Heath. 5rd ed. 2015, p110-112. Hyunmoonsa, Seoul.

10. Lee HR, Kim YS, et al. Adult Healthy Nursing. Grd ed. 2008, p1203-1206. Hyunmoonsa, Seoul.

11. Maisel, AS, Flower P, Rearden A, Motulsky h J, and Michel, MC. A new method for isolation of human lympocyte subsets reveals differential regulation of beta-adrenergic receptors by terbutaline treatment. Clin Pharmacol Ther. 1989, 46:429-439.

12. Moyna N, Acker G, Weber K. The effects of incremental submaximal exercise on circulating leukocytes in physically active and sedentary males and females. Eur J Physiol. Occup Physiol. 1996, 74:211-218.

13. Nehlsen-Cannarella SL. Cellular responses to moderate and heavy exercise. Can J Physiol Pharmacol. 1998, 76:485-491.

14. Park YM. Effect of Gravitational Stress on Immune Response Potential in Mice I. Changes of Various Immunological Parameters in Thymus. The Korean Association of Immunologists. 1996, 18;275-284.

15. Robertson A, J, Ramesar K, C, Potts R, Gibbs J, Browning M, Brown R. The effect of strenuous physical exercise on circulating blood lymhocytes and serum cortisol levels. J Clin Lab Immunol. 1981, 5:53-59.

16. Valenti M, Prozio G, Aielli F, Verna L, Cannita K and Manno R, et al. Physical exercise and quality of life in breast cancer survivors. Int J med Sci. 2008. 15:24-28.

17. Yeo NH, Kim SK. A Study on Exercise Priscription for Human Immune System. Korea Society of Exercise Physiology. 1996, 6;151-167.

18. Yoon JH, Lee JS, Jung IG. The effect of exercise quantity on the cellular and humoral immunity. Korean J. Sports Science. 1998, 7:231-240. 